\title{
Coping with Uncertainties of Doing Business for MNCs in the Gulf Cooperation Council (GCC) under the Current Situation: Case of Saudi Arabia
}

\author{
Al Zaid, Muhammad Y \\ University Of International Business \& Economics UIBE
}

\begin{abstract}
A Multinational Corporation (MNCs) is a business enterprise that manages production or delivers services in several country. Corporations have many ways to enter other countries either by Foreign Direct Investment (FDI), a Subsidiary or investing in a special economic zone.
\end{abstract}

Keywords: MNCs, GCC, Uncertainties, Oil \& Gas

\section{INTRODUCTION}

The Gulf Cooperation Council (GCC) is one of the world's most powerful economic and political unions. It consists of six Arab Countries; Saudi Arabia, United Arab Emirates (UAE), Kuwait, Oman, Qatar and Bahrain. From 1981 when GCC was formed, its main objectives have been to promote scientific, as well as technological, progress in various industries, such as mining and agriculture, develop scientific centers, come up with a common currency, and strengthen ties between all the member countries. Over the past decades, the GCC members have worked collectively in achieving these objectives ${ }^{1}$. However, the recent events of the Qatar-Gulf crisis threaten the sustainability and the ability of the GCC to deliver its mandates. On June of this year, Saudi Arabia and UAE cut their diplomatic ties with Qatar with claims of supporting terror groups within its territory. They were later joined by Bahrain and Egypt, which claimed that the assertions by UAE and Saudi Arabia to be true. The situation further worsened when President Trump accused Qatar of supporting terrorism and various terror groups. Nevertheless, according to Qatar, these accusations are false and lack evidence. It considers them a plot to sideline the country from the overall economic growth and development plans in the Gulf region.

The current Gulf crisis has caused considerable uncertainties affecting business in the region. For example, sanctions imposed on Qatar have seen a decline in its economic performance as evidenced by its fall in oil prices, as well as the number of international flights served by the country. This tendency is likely to affect the current and future performance of multinational corporations in the Gulf region. Therefore, this article aims to examine how multinational corporations can cope with uncertainties of doing business in the Gulf region, with Saudi Arabia being the country of focus. In order to realize this goal, the current political and economic of Saudi Arabia will be examined with the aim of identifying some of the uncertainties that multinational corporations face. Some alternatives will be recommended for the MNCs to adopt and remain profitable irrespective of the current situation in the region.

\section{Political Status of Saudi Arabia}

It would be appropriate to note that Saudi Arabia's political status has induced some uncertainty and questioned its sustainability. Saudi Arabia is an absolute monarchy state. Its current king and prime minister is King Salman bin Abdul Aziz Al-Saud. Unlike most of the countries in the Middle East, it remains relatively stable with limited anti-government protests witnessed in areas inhabited by the minorities. Currently, it faces uncertainties concerning its royal recession and its political stability in the wake of unfavorable political and economic ties with neighbor countries especially GCC

\footnotetext{
${ }^{1}$ Ugo Fasano and Zubair Iqbal. GCC Countries: From Oil Dependence to Diversification. (Washington, DC: International Monetary Fund, 2003), 4, 14.
} 
members. According to evidence, Saudi Arabia has a history of having been ruled by sons of its founder, Abdul Aziz al-Saud, for the last six decades. When the current leader dies, the power will be transferred to his eldest son, a fact that implies that the power will eventually reach the youngest generation of the Saudi princes. However, it presents a challenge because of the many younger princes to select. Consequently, it might cause some rivalry on the quest to control the Saudi throne ${ }^{2}$. Therefore, this acts as a considerable source of political uncertainty facing Saudi Arabia currently.

The second political uncertainty faced by Saudi Arabia stems from the current negative relations it has with Qatar. On June this year, Saudi Arabia cut its ties with Qatar because it suspected the country of sponsoring terrorism and terror groups within its territory. According to Saudi Arabia, Qatar's involvement in promoting terrorism and safeguarding terror groups is a considerable source of a security threat to its citizens. As asserted by Saudi Arabia, Qatar should end its support for terror groups and terrorism to resume their earlier relations. With continued stalemate between these countries, it remains unclear whether Saudi's decision to ban Qatar from its politics and economic development agendas will have an effect on its socio-economic and political development or not.

\section{Economic Status of SAUdi Arabia}

It is necessary to note that the main advantage of the country in terms of resources has formed its main economic weaknesses. Saudi Arabia is one of the largest economies in the Gulf region. It is among the world's leading producers, as well as exporters, of oil. It accounts for $60 \%$ of the Gulf States population with a GDP ranging between US\$ 130 and 140 billion. Despite these numbers, it faces unique economic challenges that threaten its future economic growth and sustainability. Firstly, the country relies mainly on oil production. Almost $95 \%$ of the revenue generated in the state is acquired from oil. Over the recent years, the price of oil in the world market has been unstable. The drop in oil prices mounts considerable pressure on the country to come up with additional ways of maintaining its per capita growth and other sectors of economy afloat ${ }^{3}$. Therefore, the state has been promoting growth, sustainability, and flourishing of other sectors of the economy such as manufacturing, tourism, technology and service industries as a way of reducing its overdependence on oil.

Secondly, Saudi Arabia faces the threat of terror attack from terror groups that many targeted it in the past decade. This tendency is attributed to its hard stand against these terror groups in the state. It has caused a unfavorable business environment for some investors who fear to invest in Saudi Arabia. Moreover, the absolutist monarchy state of Saudi Arabia implies that it is highly anachronistic to a higher percentage of investors, as well as foreign powers that are interested in the Saudi's market. Taking into account that Saudi Arabia operates on a feudal system (vassal) where custom, class status, and religion are central to any business undertaking, it is difficult for many outsiders to establish themselves in the state ${ }^{4}$. Thus, these economic challenges present considerable uncertainties for multinational corporations operating in Saudi Arabia and those interested in venturing into its markets.

\section{Analysis and Recommendations for Multinational Corporations in Saudi ARABIA}

Multinational Corporations in Saudi Arabia experience considerable uncertainties that threaten their performance and competitiveness. The political environment is not favorable for foreign investors in the state. With the current political stalemate regarding Qatar crisis with GCC, multinational corporations remain undetermined on whether their performance in Saudi Arabia and Qatar's markets will be affected or not. Besides, the economic challenges that Saudi Arabia is currently undergoing present harsh conditions that threaten the sustainability of multinational corporations in the country. Therefore, it is essential that they explore ways of coping up with the presented political and economic uncertainties in the country.

2 Madawi Al-Rasheed. Muted Modernists: The Struggle over Divine Politics in Saudi Arabia. (Oxford: Oxford University Press, 2016), 117

3 Zakir Hussain. Saudi Arabia in a Multipolar World: Changing Dynamics. (London: Routledge, 2016), 35

4 Ibid., 113 
Multinational corporations in Saudi Arabia can adopt several mechanisms to cope up with political and economic uncertainties they face. Firstly, they should come up with corporate goals or strategies that extend beyond their short-term gains for their shareholders. The focus should be on meeting the long-term interests of their stakeholders. Consequently, the main goal of undertaking their businesses should be to strengthen their corporate social responsibility and not just to be philanthropic appendages in the state. For example, multinational corporations specializing in the banking industry should focus on promoting the financial security of their customers for macroeconomic stability while those in the oil producing industry should focus on protecting the environment ${ }^{5}$. Through following this direction, they will capitalize on the presented opportunities while minimizing the negative effects brought by the unfavorable conditions in the marketplace.

Multinational corporations in Saudi Arabia can also adapt to the current uncertainties by shifting their business models from the traditional approaches to business undertaking to global-local hybrid business models. As the political and economic conditions in Saudi Arabia deteriorate, the traditionally held systems of governance, such as centralized governance, will not work for the MNCs. As a result, they should evolve from employing the use of globally integrated business governance models to quasi-independent business methods that will give them their desired flexibility in making business decisions that align with economic nationalism brought by the current uncertainties $^{6}$. By means of the application of this approach, they will benefit from being able to make fewer and deeper strategic initiatives that are specific to their target markets.

Moreover, they should consider adopting cost-cutting initiatives as a way of coping up with the current uncertainties in GCC's markets. The companies should come up with strategic commitments that lower the overall costs incurred while increasing the revenue accrued from engaging in organizational activities. For example, they should focus on innovating their products and services as a way of creating value, a fact that results in a decline in the uncertainty associated with the burden of production expenses. They can also use their operational hedge to minimize the undesired effects of their uncertainties on their performance. Therefore, the focus should be on switching sourcing strategies and contingencies on demand based on the exchange rate uncertainties and delaying or holding the excess capacity investments. ${ }^{7}$. When these measures are taken, the multinational corporations will acquire their desired competitive edge due to their increased focus on a specific market needs rather than the general wants among the target consumers.

Multinational corporations in Saudi Arabia should also consider adopting reverse innovation as a way of coping up with the increasing political and economic uncertainties. Reverse innovation refers to a process whereby production processes in firms are done with the use of inexpensive models to meet the needs of emerging markets in developing countries. In this case, MNCs should envisage diversifying their production processes in other countries where their target markets are not fully exploited. Through following this way, they will benefit from sustained performance across their global branches irrespective of the harsh conditions it faces in Saudi Arabia.

Besides, they should consider externalizing their operations through joint ventures as a way of adapting to the new changes in their current Saudi markets. In this strategy, MNCs should focus on reducing the cost of adapting to the effects brought by the uncertainties. It is possible if they consider marketing their original brands as premium brand imports while creating the locally available brands to reach a higher percentage of customers without downgrading the image of their brands ${ }^{8}$. Other ways in which MNCs in Saudi Arabia can cope up with the increasing uncertainties brought by the Qatar-Gulf crisis include its utilization of the exchange rate uncertainty where it can

5 Peter Marris. The Politics of Uncertainty: Attachment in Private and Public Life. (London: Routledge, 2003), 11

6 Bret Lee Billet. Investment Behavior of Multinational Corporations in Developing Areas: Comparing the Development Assistance Committee, Japanese, and American Corporations. (Piscataway, NJ: Transaction Publishers, 1991), 12-13

7 Alan C. Shapiro. Multinational Financial Management. (New, York, NY: John Wiley \& Sons, 2009), 277

8 Ian Bremmer and Preston Keat. The Fat Tail: The Power of Political Knowledge for Strategic Investing. (Oxford: Oxford University Press, 2010), 102, 157-158 
either choose to remain passive irrespective of the situation it faces or hedge its performance through the money market.

\section{Conclusion}

The current Qatar-Gulf crisis is causing considerable political and economic uncertainties in Saudi Arabia. With the current state, it is unclear whether the continued conflict between Saudi Arabia and Qatar will have a significant effect on the Saudi's overall economic and political stability. Finally, investors and multinational corporations in Saudi Arabia suffer from this event. As a result, it is important that they come up with responsive measures that would facilitate their successful adaptation with the potential outcomes brought by the stalemate between Saudi Arabia and Qatar.

\section{REFERENCES}

[1] Al-Rasheed, Madawi. Muted Modernists: The Struggle over Divine Politics in Saudi Arabia. (Oxford: Oxford University Press, 2016).

[2] Billet, Bret Lee. Investment Behavior of Multinational Corporations in Developing Areas: Comparing the Development Assistance Committee, Japanese, and American Corporations. (Piscataway, NJ: Transaction Publishers, 1991).

[3] Bremmer, Ian, and Preston Keat. The Fat Tail: The Power of Political Knowledge for Strategic Investing. (Oxford: Oxford University Press, 2010).

[4] Fasano, Ugo, and Zubair Iqbal. GCC Countries: From Oil Dependence to Diversification. (Washington, DC: International Monetary Fund, 2003).

[5] Hussain, Zakir. Saudi Arabia in a Multipolar World: Changing Dynamics. (London: Routledge, 2016).

[6] Marris, Peter. The Politics of Uncertainty: Attachment in Private and Public Life. (London: Routledge, 2003).

[7] Shapiro, Alan C. Multinational Financial Management. (New, York, NY: John Wiley \& Sons, 2009) 